\title{
The Attempt to Human Rights Protection Through Judicial Review in Indonesia
}

\author{
Riris Ardhanariswari 1,*, Muhammad Fauzan ${ }^{2}$, and Ahmad Komari ${ }^{3}$ \\ ${ }^{1}$ Faculty of Law, Jenderal Soedirman University, Indonesia \\ ${ }^{2}$ Faculty of Law, Jenderal Soedirman University, Indonesia \\ ${ }^{3}$ Faculty of Law, Jenderal Soedirman University, Indonesia
}

\begin{abstract}
The Constitutional Court is one of the perpetrators of judicial power, in addition to the Supreme Court as referred to in Article 24 paragraph (2) of the 1945 Constitution. The Constitutional Court is also bound to the general principle of an independent judicial power, free from the influence of other institutions in enforcing law and justice. The Constitutional Court is the first and last level judicial body, or it can be said that it is the only judicial body whose decisions are final and binding. The existence of the Constitutional Court is at the same time to maintain the implementation of a stable state government and is also a correction to the experience of constitutional life in the past caused by multiple interpretations of the constitution. Judicial review towards the constitution is one of the authorities of the Constitutional Court that attracted attention. This shows that there has also been a shift in the doctrine of the parliamentary supremacy towards the doctrine of the supremacy of the constitution. The law was previously inviolable, but now the existence of a law is questionable in its alignment with the Constitution. The authority to examine the Law towards the Constitution is the authority of the Constitutional Court as the guardian of the constitution. This authority is carried out to safeguard the provisions of the Act so that it does not conflict with the constitution and / or impair the constitutional rights of citizens. This shows that the judicial review towards the Constitution carried out by the Constitutional Court is basically also to provide protection for human rights.
\end{abstract}

\section{Introduction and Literary Review}

The amendment to the 1945 Constitution had an impact on the constitutional structure in Indonesia, one of which was the existence of a new institution, namely the existence of the Constitutional Court (MK). The Constitutional Court (hereinafter abbreviated as MK) is one of the perpetrators of judicial power, in addition to the Supreme Court as referred to in Article 24 paragraph (2) of the 1945 Constitution. This means that the Constitutional Court is bound to the general principle of the exercise of an independent judicial power, free from the influence of other institutions to enforce law and justice [1]. Furthermore Article 24

\footnotetext{
* Corresponding author: ririsardhana@gmail.com
} 
paragraph (2) asserts: Judicial power is carried out by a Supreme Court and the judiciary under it in the general court environment, religious court environment, military court environment, state administrative court environment, and by a Constitutional Court. Article 24 C paragraph (1) of the 1945 Constitution affirms: The Constitutional Court has the authority to adjudicate at the first and last level whose decisions are final to examine the law towards the Constitution, decide on disputes over the authority of state institutions whose authority is granted by the Constitution, decide dissolution of political parties, and deciding disputes concerning the results of general elections.

Constitutional authorities of the Constitutional Court implement the principle of checks and balances by placing all state institutions in equal positions so that there is a balance in the administration of the state. The existence of the Constitutional Court is a concrete step to be able to correct each other's performance among state institutions. The Constitutional Court is the first and last level judicial body, or it can be said that it is the only judicial body whose decisions are final and binding. This shows that the Constitutional Court handled certain cases in the state administration, in order to maintain the constitution to be carried out responsibly in accordance with the will of the people and the ideals of democracy. The existence of the Constitutional Court is at the same time to maintain the implementation of a stable state government, and also a correction to the experience of state administration in the past caused by multiple interpretations of the constitution [2].

One of the authorities of the Constitutional Court that attracted the attention of the public was the authority to examine the constitutionality of an Act towards the Constitution or constitutional review [3]. Interestingly, because of judicial review towards the constitution, the presence of the Constitutional Court shifted the parliamentary supremacy doctrine towards the doctrine of the supremacy of the constitution. In the past, the legislative product law could not be contested, but now it can be questioned in harmony with the constitution. Because in reality, it is not impossible that the law as a product of a political institution contains elements of interest that are contrary to the constitution [4]. The authority to examine the Act towards the Constitution is the authority of the Constitutional Court as the guardian of the constitution (The Guardian of the Constitution). This authority is carried out to safeguard the provisions of the Act so that it does not conflict with the constitution and or impair the constitutional rights of citizens. This is interesting to do research related to the judicial review that is correlated with the protection of human rights.

\section{Objective of the Study}

This article describes the correlation between the protection of human rights through judicial review and the efforts made.

\section{Methodology}

The statutory approach is intended to examine the applicable laws (positive law) governing the implementation of the authority to test (the judicial review) of the Constitutional Court. Whereas the conceptual approach is carried out by studying and analyzing various concepts and doctrines and theories related to judicial review.

\section{Discussion}

The Constitutional Court which has the authority to adjudicate the final, to examine the constitutionality of the Act, is an important change in the life of the Indonesian state administration. The existence of a law that has been determined by people's representatives 
has the opportunity to violate the 1945 Constitution. Also it is possible for a law not to be responsive and even inhibits and violates the highest political agreement of the people in the constitution.

Democratization in the formation of law is one of the important aspects in a constitutional democracy because the enactment of a law can bring change and progress to the nation, but also the existence of the law will violate the constitutional rights of citizens protected by the constitution. Applicability of a law can also benefit certain people or groups. The existence of the Constitutional Court is certainly in the hope as an institution that will implement checks and balances on the legislative body.

Related with the authority of the Constitutional Court to examine the Law towards this Constitution, the Constitutional Court has sought to maintain legal products in the form of laws in accordance with the constitution, namely both the formation and material so that they are in line with the objectives of law and democracy in the opening as well as the body of the 1945 Constitution, as a place to resolve constitutional problems through the authority to declare unconstitutionally and not bind a law or form the law in a negative sense (negative legislation). The Constitutional Court also strengthens the principle of the rule of law by upholding the rule of law (supremacy of law), giving equality before the law and enforcing a constitution based on human rights.

The existence of the Constitutional Court's decision relating to the review of the Act may result in the cancellation of all or parts or articles or verses of a Law. The existence of the Constitutional Court's decision brought changes to a law, both with regard to paragraphs, articles, sections or laws as a whole. Article 51 of Law No. 24 of 2003 concerning the Constitutional Court affirms as follows: (1) the Petitioner is a party who considers his constitutional rights and / or authority to be impaired by the coming into effect of the Act, namely: Individual Indonesian citizens; Customary law communities as long as they are alive and in accordance with the development of the community and the principles of the Unitary Republic of Indonesia that are regulated in the Act; Public or private legal entity; or State Institution (2) The Applicant must clearly explain in his petition about his constitutional rights and / or authorities as referred to in paragraph (1). Explanation of Article 51 describes that what is meant by "constitutional rights" are the rights regulated in the 1945 Constitution. The explanation of Article 51 paragraph (1) letter a that what is meant by "individual" includes groups of people who have the same interests. Based on the provisions of Article 51 and its explanation, there are no criteria regarding the loss of constitutional rights and / or authorities which are impaired by the coming into effect of an Act.

The Decision of the Constitutional Court Case No. 006 / PUU-III / 2005 concerning judicial review No. 32 of 2004 concerning Regional Government dated 31 May 2005 and the Decision of the Constitutional Court Case No. 11 / PUU-V / 2007 concerning judicial review No. 56 Prp of 1960 concerning the Determination of Agricultural Land Area and in subsequent decisions that the impairment of constitutional rights and / or authorities impaired by the coming into effect of an Act must fulfill the following five conditions: (1) The constitutional rights and / or authorities granted by the 1945 Constitution; (2) The applicant's constitutional rights and / or authorities are deemed by the applicant to have been impaired by the coming into effect of the Law petitioned for review; (3) These losses are specific (specific) and actual or at least potential in nature which according to logical reasoning can be ascertained; (4) The existence of a causal relationship (causal verband) between the said loss and the coming into effect of the Law petitioned for review; and (5) There is a possibility that with the granting of the petition, the impairment of constitutional rights and / or authority as argued will not or will not occur again. This shows that relating to who can become an applicant in a judicial review, the law has been extended by the Constitutional Court.

The Constitutional Court in the decision does not elaborate on the background or the reason for the emergence of criteria for the impairment of constitutional rights and / or 
authorities which have been impaired by the coming into effect of an Act, which exists that the five conditions must be cumulative. According to the author, the Constitutional Court has provided a description of the criteria regarding the loss of constitutional rights and / or authority. MK Regulation No. 06 / PMK / 2005 concerning Guidelines on Procedures in the case of judicial review also does not regulate the criteria for the loss of constitutional rights and / or authorities. The existence of amendments to the Constitutional Court Law, namely with the existence of Law No. 8 of 2011 concerning Amendments to Law No. 24 of 2003 concerning the Constitutional Court also does not regulate the criteria for the loss of constitutional rights and / or authority. This new law should contain the regulation of these criteria. Does the legislator not know of the Constitutional Court Decision No. Case 006 / PUU-III / 2005 concerning of judicial review No. 32 of 2004 concerning Regional Government dated 31 May 2005 and the Decision of the Constitutional Court Case No. 11 / PUU-V / 2007 concerning judicial review No. 56 Prp of 1960 concerning Establishment of Agricultural Land Area. The Constitutional Court in every decision related to the legal standing of the applicant always includes the decision. Lawmakers should include criteria for the loss of constitutional rights and / or authorities in the Constitutional Court Law. This means that with the existence of the Constitutional Court's decision relating to legal standing, it has experienced an extension of the legal standing of the judicial review [5].

Corresponds to individuals who can submit a petition for judicial review of the Law, the Constitutional Court has issued several decisions relating to the applicant are individuals, namely: Decision of the Constitutional Court Number 27 / PUU-VII / 2009 concerning judicial review of the MA Law, Constitutional Court Decision Number 5 / PUU-IX / 2011 concerning judicial review of the Corruption Eradication Commission Law, Constitutional Court Decision Number 49 / PUU-IX / 2011 concerning the judicial review of the Constitutional Court Law and the Constitutional Court Decision Number 81 / PUU-IX / 2011 regarding the judicial review of the Election Law provides recognition to taxpayers as Petitioners in judicial review of the Act. The Constitutional Court applies the minimum legal standing requirement of a taxpayer in the law, namely taxpayers from various associations and NGOs / NGOs concerned with a law in the public interest, legal entities, regional governments, state institutions, and others. The legal position of taxpayers to submit applications may not be generalized or generalized to all cases so that taxpayers are not obscene in submitting applications for judicial review. A taxpayer can be allowed to have a legal standing on the enactment of a law but also has the opportunity to not have legal standing for the examination of other laws. There are two important things that a taxpayer must prove to get a legal position. To achieve justiciability is related to a constitutional loss requirement that is specific and actual in nature or at least potential and a causal relationship between the loss and the application of the Law petitioned for review. First, there must be a logical link between the status as a taxpayer and the "Law petitioned for review". Second, the taxpayer must prove the existence of a nexus (relationship) between his status as a taxpayer and the constitutional violations he argued. [6]

One of the controversial decisions of the Constitutional Court according to the author relating to efforts to protect human rights through the judicial review is the Constitutional Court Decision No. Case 138 / PUU-VII / 2009 concerning a review of Government Regulation in Lieu of Law Number 4 of 2009 concerning Amendments to Law No. 30 of 2002 concerning the Corruption Eradication Commission and the Constitutional Court Decision Case No. 145 / PUU-VII / 2009 concerning judicial review No. 6 of 2009 concerning the Stipulation of Government Regulation in Lieu of Law Number 2 of 2008 concerning the Second Amendment to Law No. 23 of 1999 concerning Bank Indonesia into Law No. 3 of 2004 concerning Amendments to Law No. 23 of 1999 concerning Bank Indonesia, and Government Regulation in Lieu of Law Number 4 of 2008 concerning Financial System Safety Net (JPSK). 138 / PUU-VII / 2009, the Constitutional Court was 
authorized to test the Perpu. This is a breakthrough made by the Constitutional Court relating to the authority of the Constitutional Court in judicial review towards the Constitution, but this Constitutional Court decision also indirectly changes Article 24C paragraph (1) of the 1945 Constitution and Article 10 paragraph (1) of Law No. 24 of 2003 concerning the Constitutional Court as amended by Law No. 8 of 2011 concerning Amendments to Law No. 24 of 2003 concerning the Constitutional Court. One of the judges' considerations in the ruling is that the Perpu gave birth to legal norms and a new legal norm would be able to lead to: (a) new legal status, (b) new legal relations, and (c) new legal consequences. The legal norm was born since the Perpu was ratified and the fate of the legal norm depends on the approval of the DPR to accept or reject the legal norms of the Perpu, however before the opinion of the House of Representatives to reject or approve the Perpu, the legal norms are valid and act like the Law. Because it can lead to legal norms that are binding on the same power as the Law, the norms contained in the Perpu can allow the Court to test whether it is materially contradictory to the 1945 Constitution. Thus, the Court has the authority to examine Perpu towards the 1945 Constitution prior to the rejection or approval by the DPR, and after the approval of the DPR because the Perpu has become a Law [7].

Mahfud MD as a constitutional judge has a concurring opinion. He argued that the Perpu could be tested by the Constitutional Court through an emphasis on sociological and teleological interpretations. The emphasis of choice on such interpretations does indeed set aside historical and grammatical interpretations, even out of the original intent of the provisions concerning the Perpu as stipulated in Article 22 of the 1945 Constitution. This needs to be done precisely to protect the interests of the article's original intent and other principles also exist in the 1945 Constitution. The choice of this view is based solely on the principle of maintaining the constitution which is "not even one second have laws that have the potential to violate the constitution without being straightened out or tested through judicial testing" [7]. This shows that the protection of human rights is put forward in the judicial review.

According to Titon Slamet Kurnia, the protection of human rights through the judicial review by the constitutional court is one of the important theories in explaining the judicial constitutionality of the law. Although not a part of the process of debating the formation of the Constitutional Court, this theory applies taken for granted to the Constitutional Court. This is because the theory has become mainstream in the authoritative opiniono doctorum at the moment [8].

The existence of the Constitutional Court in Indonesia is certainly in the framework of strengthening the principle of the rule of law by upholding the rule of law (supremacy of law), providing equality before the law and enforcing a constitution based on human rights.

\section{Conclusion}

The judicial review conducted by the Constitutional Court has become an important decision landmark in the development of human rights in Indonesia. The Constitutional Court's decision to expand legal standing in the judicial review is an effort to protect human rights. The decision of the Constitutional Court which ruled that the Perpu could be requested to examine the law was a breakthrough by prioritizing the aspirations of human rights protection. 


\section{References}

1. B. Sutiyoso, Hukum Acara Mahkamah Konstitusi Republik Indonesia (Procedural Law of the Constitutional Court of the Republic of Indonesia) (Citra Aditya Bakti, Bandung, 2006)

2. General Explanation of Law No. 24 of 2003 concerning the Constitutional Court.

3. M. Mahfud MD, Judicial Review dalam Politik Hukum Nasional (Judicial Review in Politics of National Law), a paper presented at a seminar on Judicial Review and Direction of Political Law organized by the Department of Law and Citizenship, Semarang State University, 17 April 2006

4. Fadjar Laksono, J. Konstitusi, 5, 15 (2008)

5. R. Ardhanariswari, Dissertation in Padjajaran University, "The Jurisdiction of the Constitutional Court to Conduct Tests of Laws Against the Constitution and Its Implications for the Development of National Law" (Bandung, 2013)

6. Decision of the Constitutional Court Number 31 / PUU-X / 2012 concerning Testing of Law No. 30 of 2002 concerning the Corruption Eradication Commission.

7. Decision of the Constitutional Court Case No. 138 / PUU-VII / 2009 concerning Testing of Government Regulation in Lieu of Law Number 4 of 2009 concerning Amendments to Law No. 30 of 2002 concerning the Corruption Eradication Commission.

8. T. S. Kurnia, J. Yuridika, 28, 288 (2013) 